\title{
Evaluation of heated air jet on pulp chamber temperature at different steps of the restorative protocol
}

\author{
Avaliação do jato de ar aquecido na temperatura da câmara de polpa em diferentes etapas do \\ protocolo de restauração \\ Evaluación del chorro de aire calefactado sobre la temperatura de la cámara de pulpa en diferentes \\ pasos del protocolo de restauración
}

Received: 06/02/2021 | Reviewed: 06/13/2021 | Accept: 06/17/2021 | Published: 07/02/2021

\author{
Bruna Souza Andrade \\ ORCID: https://orcid.org/0000-0002-6447-3398 \\ Universidade do Oeste Paulista, Brazil \\ E-mail: brunandrade30@hotmail.com \\ Sheyla Adriane Rodrigues Oliveira João \\ ORCID: https://orcid.org/0000-0002-7227-0734 \\ Universidade do Oeste Paulista, Brazil \\ E-mail: sheylaadriane@hotmail.com \\ Larissa Sgarbosa de Araújo Matuda \\ ORCID: https://orcid.org/0000-0002-9033-9029 \\ Universidade do Oeste Paulista, Brazil \\ E-mail: larissa_sna@yahoo.com.br \\ Juliane Avansini Marsicano \\ ORCID: https://orcid.org/0000-0002-8213-1754 \\ Universidade do Oeste Paulista, Brazil \\ E-mail: juliane@unoeste.br \\ Rosana Leal Prado \\ ORCID: https://orcid.org/0000-0002-5897-2799 \\ Universidade do Oeste Paulista, Brazil \\ E-mail: rosana@unoeste.br \\ Eliane Cristine Gava Pizi \\ ORCID: https://orcid.org/0000-0002-8750-7669 \\ Universidade do Oeste Paulista, Brazil \\ E-mail: elianepizi@unoeste.br
}

\begin{abstract}
Objectives: Evaluate of the heated air jet temperature (T) in the pulp chamber on cavity 5 depths and photoactivation stages for a bulk fill resin restorative protocol is evaluated. Methods: Class I cavity preparations were conducted at different depths $(n=8)$ through two protocols for adhesive volatilization $\left(23{ }^{\circ} \mathrm{C}\right.$ and $\left.40{ }^{\circ} \mathrm{C}\right)$ and cavities were restored with the Filtek Bulk Fill resin. The pulp chamber temperature variation was evaluated at four steps (times) during the restorative protocol: I (initial), V (after volatilization), A (after photoactivation of the adhesive), and C (after photoactivation of the composite resin). To verify the assumptions of the normality of the errors and homoscedasticity, the Shapiro Wilk and Levene tests were conducted. Subsequently, two-way and three-way analysis of variance was carried out, followed by Tukey's post-hoc analysis $(\alpha=0.05)$. Results: The maximum $\mathrm{T}$ at the different restorative steps, regardless of the volatilization protocol and cavity depth, was as follows: I $\left(36.8{ }^{\circ} \mathrm{C}\right)=\mathrm{V}\left(36.9^{\circ} \mathrm{C}\right)<\mathrm{A}(37.2$ $\left.{ }^{\circ} \mathrm{C}\right)=\mathrm{R}\left(37.8^{\circ} \mathrm{C}\right)(\mathrm{p}<0.05)$. During $\mathrm{V}$, a small greater variation was observed in pulp chamber temperature when dentin was volatilized at $40{ }^{\circ} \mathrm{C}(\mathrm{p}<0.05)$ at very deep cavity depths $\left(0.31^{\circ} \mathrm{C}\right)$. The largest temperature variations $(\mathrm{p}$ $<0.05)$ were observed during $\mathrm{A}\left(0.17-0.59^{\circ} \mathrm{C}\right)$ and $\mathrm{R}\left(0.50-1.06^{\circ} \mathrm{C}\right)$, reaching peak temperatures in the cavities.
\end{abstract}

Keywords: Temperature; Dental restoration, permanent; Dental pulp cavity; Volatilization.

\section{Resumo:}

Objetivos: Avaliar a temperatura do jato de ar aquecido (T) na câmara pulpar na cavidade 5 profundidades e estágios de fotoativação para um protocolo de restauração de resina de bulk fill. Métodos: Os preparos cavitários Classe I foram conduzidos em diferentes profundidades $(n=8)$ por meio de dois protocolos de volatilização do adesivo $\left(23^{\circ}\right.$ $\mathrm{C}$ e $40^{\circ} \mathrm{C}$ ) e as cavidades foram restauradas com a resina Filtek Bulk Fill. A variação da temperatura da câmara pulpar foi avaliada em quatro etapas (tempos) durante o protocolo restaurador: I (inicial), V (após volatilização), A (após fotoativação do adesivo) e C (após fotoativação da resina composta). Para verificar os pressupostos de normalidade dos erros e homocedasticidade, foram realizados os testes de Shapiro Wilk e Levene. Posteriormente, foi realizada a análise de variância de dois e três fatores, seguida da análise post-hoc de Tukey $(\alpha=0,05)$. Resultados: $\mathrm{O}$ 
T máximo nas diferentes etapas da restauração, independentemente do protocolo de volatilização e da profundidade da cavidade, foi o seguinte: $\mathrm{I}\left(36,8^{\circ} \mathrm{C}\right)=\mathrm{V}\left(36,9^{\circ} \mathrm{C}\right)<\mathrm{A}\left(37,2^{\circ} \mathrm{C}\right)=\mathrm{R}\left(37,8^{\circ} \mathrm{C}\right)(\mathrm{p}<0,05)$. Durante $\mathrm{V}$, uma pequena variação maior foi observada na temperatura da câmara pulpar quando a dentina foi volatilizada a $40^{\circ} \mathrm{C}(\mathrm{p}<0,05)$ em profundidades cavitárias muito profundas $\left(0,31^{\circ} \mathrm{C}\right)$. As maiores variações de temperatura $(\mathrm{p}<0,05)$ foram observadas durante A $\left(0,17-0,59^{\circ} \mathrm{C}\right)$ e $\mathrm{R}\left(0,50-1,06^{\circ} \mathrm{C}\right)$, atingindo picos de temperatura nas cavidades.

Palavras-chave: Temperatura; Cavidade pulpar; Restauração dentária permanente; Volatilização.

\section{Resumen}

Objetivos: Evaluar la temperatura del chorro de aire caliente $(\mathrm{T})$ en la cámara pulpar en las profundidades de la cavidad 5 y las etapas de fotoactivación para un protocolo de restauración de resina de relleno a granel. Métodos: Se realizaron preparaciones de cavidades de clase I a diferentes profundidades $(n=8)$ mediante dos protocolos de volatilización del adhesivo $\left(23^{\circ} \mathrm{C} \mathrm{y} 40^{\circ} \mathrm{C}\right.$ ) y se restauraron las cavidades con la resina Filtek Bulk Fill. La variación de la temperatura de la cámara pulpar se evaluó en cuatro pasos (tiempos) durante el protocolo de restauración: I (inicial), V (después de la volatilización), A (después de la fotoactivación del adhesivo) y C (después de la fotoactivación de la resina compuesta). Para verificar los supuestos de normalidad de los errores y homocedasticidad, se realizaron las pruebas de Shapiro Wilk y Levene. Posteriormente, se realizó un análisis de varianza de dos y tres vías, seguido del análisis post-hoc de Tukey $(\alpha=0.05)$. Resultados: La T máxima en los diferentes pasos restauradores, independientemente del protocolo de volatilización y la profundidad de la cavidad, fue la siguiente: I $\left(36,8^{\circ} \mathrm{C}\right)=\mathrm{V}\left(36,9^{\circ} \mathrm{C}\right)<\mathrm{A}\left(37,2^{\circ}\right.$ $\mathrm{C})=\mathrm{R}\left(37,8^{\circ} \mathrm{C}\right)(\mathrm{p}<0,05)$. Durante $\mathrm{V}$, se observó una variación ligeramente mayor en la temperatura de la cámara pulpar cuando la dentina se volatilizó a $40^{\circ} \mathrm{C}(\mathrm{p}<0,05)$ a profundidades de cavidad muy profundas $\left(0,31^{\circ} \mathrm{C}\right)$. Las mayores variaciones de temperatura $(\mathrm{p}<0.05)$ se observaron durante $\mathrm{A}\left(0.17-0.59^{\circ} \mathrm{C}\right)$ y $\mathrm{R}\left(0.50-1.06{ }^{\circ} \mathrm{C}\right)$, alcanzando temperaturas máximas en las cavidades.

Palabras clave: Temperatura; Cavidad pulpar; Restauración dental permanente; Volatilización.

\section{Introduction}

Dentin adhesives have the following components: resinous monomers, polymerization initiators, inhibitors or stabilizers, solvents, and particles of inorganic charge. The bond between the composite resin and dentin is determined by the infiltration of monomers in the intertubular matrix (due to demineralization), formation of intratubular resin tags (due to hybridization), and chemical bonding to the dental surface. However, the effectiveness of adhesive systems can be compromised by microleakage and water absorption (Van Landuyt et al., 2007; Caiado et al., 2010; Osorio et al., 2010; Amaral et al., 2016; Borgo et al., 2019).

The monomers are diluted in organic solvents that have the function of improving diffusion in the demineralized structure, thus promoting dentin dehydration so that resinous monomers can fill the surface maintained under the aqueous condition. Therefore, the monomer is the main factor that can change the effectiveness and manipulation of the adhesive system (Van Landuyt, et al., 2007; Giannini, et al., 2008; Chiba, et al., 2016)

Thus, it is essential that appropriate volatilization of the material occurs at the restoration stage, prior to polymerization, in order to maintain high-quality hybridization, because high volume of organic solvents can inhibit polymerization and impede the development of a well-defined polymer (De Munck, et al., 2005; Amaral, et al., 2016; Chiba, et al., 2016; Matuda, et al., 2016; Dreweck, et al., 2021).

The use of a heated air jet for volatilization in adhesive systems has been evaluated in some studies. The use of this jet is promising because of the high bond strength values achieved for the resin/dentin interface (Alexandre, et al., 2008; KleinJúnior, et al., 2008; Reis, et al., 2009; Reis, et al., 2010; Ogura, et al., 2012), in addition to higher stability imparted to the dentin matrix and the best module of long-term elasticity achieved for macro hybrid layer models (Matuda, et al., 2016; FerreiraBarbosa, et al., 2020).

However, the possibility of injuries to the complex pulp dentin has been a concern because heat is the most impactful factor that can cause pulp injury (Giannini, et al., 2008). Zach and Cohen achieved thermal controlled intrapulpal $2.2^{\circ} \mathrm{C}$, wherein induction of minor histological alteration occurred, and at $5.5^{\circ} \mathrm{C}$, pulp necrosis occurred in $15 \%$ of cases. They also observed 
that in all cases, increases of $11{ }^{\circ} \mathrm{C}$ and $22{ }^{\circ} \mathrm{C}$ caused considerable cell destruction with pulp necrosis and abscesses. Thus, the limit must not reach or exceed $5.5^{\circ} \mathrm{C}$ above the intrapulpal temperature to ensure dental safety (Zach \& Cohen, 1965).

Moreover, further studies investigated the pulp chamber temperature as a parameter on the basis of the pioneering laboratory research of Hanning et al. (1999) on the consequences of using light sources to significantly increase the temperature intrapulpal. More recently, in vivo studies were conducted to evaluate the increase in pulp chamber temperature during dentin exposure by using a photoactivator and the effectiveness of direct air spraying for $30 \mathrm{~s}$ immediately after turning it off in reducing the increase in pulp chamber temperature during this exposure (Hanning \& Bott, 1999; Zarpellon, et al., 2018; Zarpellon, et al., 2019).

For further investigation of the damage to the pulp tissue, cytotoxicity analyzes were performed, it is known that dentin adhesives have a toxic capacity to human cells (Huang, et al., 2010), and that the greater the thickness of dentin, the lower the cytotoxicity in comparison with smaller thicknesses (Nasseri, et al., 2020), therefore, the protection of the dentin-pulp complex must be oriented according to the remaining thickness of the dentin.

This study aimed to evaluate of the heated air jet temperature (T) in the pulp chamber on cavity 5 depths and photoactivation stages for a bulk fill resin restorative protocol is evaluated. The null hypothesis tested in this study was that the heated air jet used in the volatilization of the solvent of the universal adhesive system would negatively influence in the variation of the pulp chamber temperature, regardless of cavity depth, in bulk fiil composite restorations.

\section{Materials and Methods}

\subsection{Teeth selection}

After approval by the Research Ethics Committee (CEP) (CAAE: 82161718.2.0000.5515), 80 extracted sound third molar teeth were selected. To select these extracted teeth, the inclusion criteria were: teeth of young patients within the age group of 18 to 30 years old who were recently extracted, and teeth with similar dimensions and pulp volume, for this, digital periapical radiographs were taken to assess the distance from the occlusal to the pulp. Third molars from patients outside this age group and with different pulp dimensions and volume were excluded from the study. After selection, the Unwest Human Teeth Biobanco protocol was followed, which includes disinfection prior to immersion in enzymatic detergent for 30 min; prewash with running water, detergent and sponge; teeth scraping (for removal of organic residues); distribution in specific recipients and numbering for identification (to ensure donor confidentiality); storage in distilled water (under refrigeration, the water being changed weekly).

Digital periapical radiography was performed for all teeth to assess the distance between the occlusal surface and the pulp. Only teeth with similar dimensions and pulp volume were used in the study. The control (CT) group had a dentin thickness of $5 \pm 1 \mathrm{~mm}$, shallow cavity (SC) depth of $0.5-1.0 \mathrm{~mm}$ beyond the amelodentinary junction, middle cavity (MC) depth of 1.0 $2.0 \mathrm{~mm}$ beyond the amelodentinary junction, deep cavity (DC) depth exceeding $50 \%$ dentin thickness with at least $0.5 \mathrm{~mm}$ of remaining dentin; and the very deep cavity (VDC) depth of $<0.5 \mathrm{~mm}$ of remaining dentin.

\subsection{Outline}

For the experimental design, the teeth were divided into 10 groups according to the cavity depth (5 levels) and the air jet temperature for the solvent volatilization adhesive system ( 2 levels) $(n=8)$. The pulp chamber temperature was evaluated for each group in five different stages of the restorative protocol (Figure 1). 
Figure 1 - Schematic representation of the experimental design.

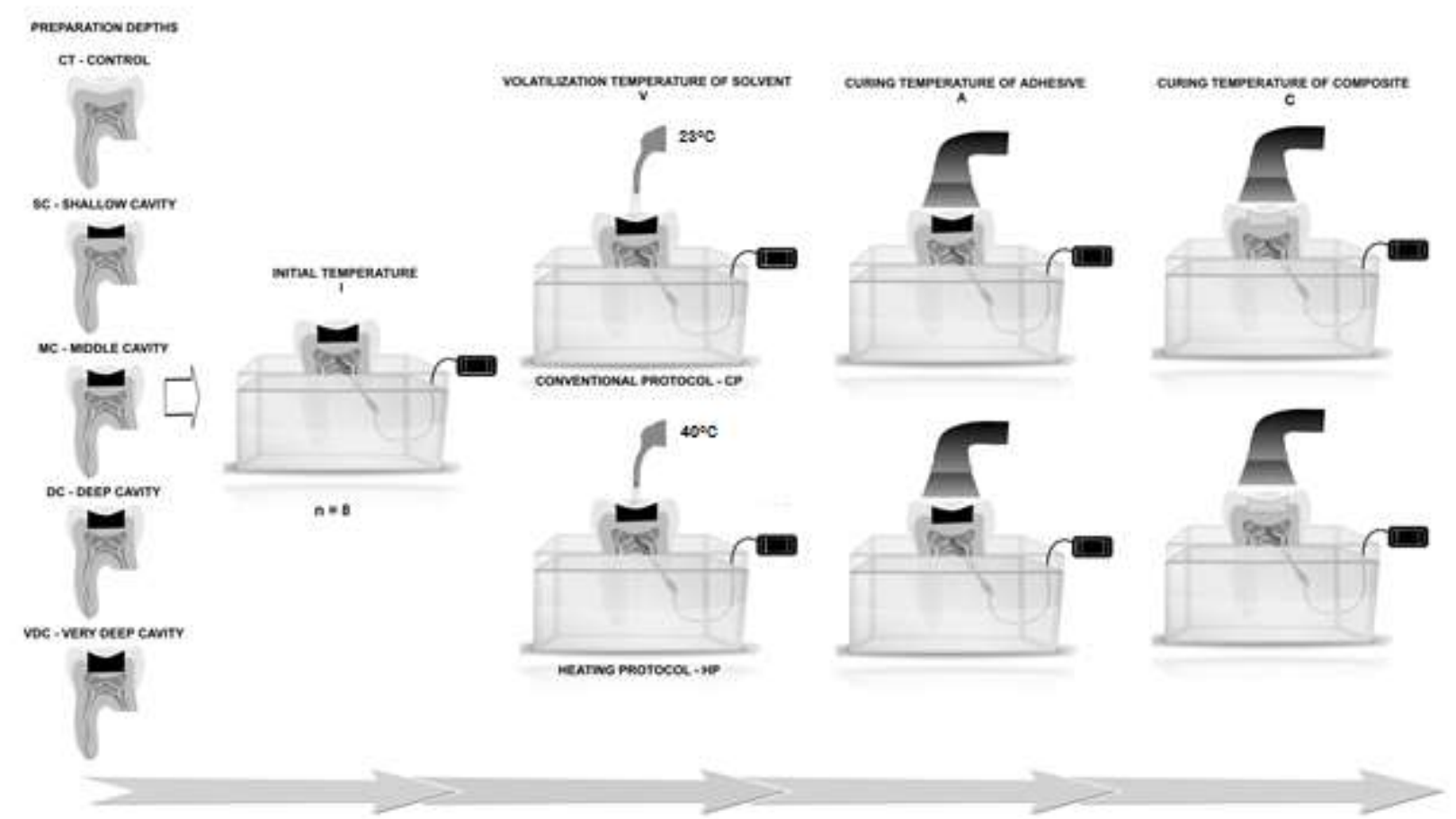

Source: Authors.

\subsection{Procedure}

Class I cavity preparations were conducted on the occlusal surface of the third molars with different cavity depths (Cavalcanti, 2010) and distributed between groups: control group (CT), shallow cavity (SC), middle cavity (MC), deep cavity (DP), and very deep cavity (VDC). Cavities with isthmus width equal to intercuspal distance were prepared by using a diamond bur (1050; KG Sorensen, Barueri, SP, Brazil) mounted on a high-speed hand-piece with an air-water spray. After the end of each cavity preparation, new periapical radiographs were obtained to confirm the cavity depth and thickness between the dentin and pulp. Subsequently, the sectioning of the root portion was performed $2 \mathrm{~mm}$ below the enamel/cement joint with disk Diamond Flex - 7020 (KG Sorensen, Barueri, SP, Brazil). The root canals were enlarged, and the sections were cleaned by irrigation with a physiological solution.

\subsection{Volatilization protocol of the adhesive system at different temperatures}

The application of the Universal Single Bond adhesive system (3M, St. Paul, Minessota, USA) followed the manufacturer's protocol for selective enamel conditioning, which included prior acid conditioning of the cavity with Ultra Etch $35 \%$ phosphoric acid gel (Ultradent, Barueri, SP, Brazil) only in the enamel at the cavo-superficial angle for $30 \mathrm{~s}$ and abundant washing with an air/water jet for $60 \mathrm{~s}$. After the application of the adhesive system for $20 \mathrm{~s}$, the air jet at $23{ }^{\circ} \mathrm{C}$ (conventional protocol - CP) or $40{ }^{\circ} \mathrm{C}$ (heating protocol - HP), depending on the group, was applied at a distance of $7 \mathrm{~cm}$ between the exit of the applicator cannula and the dental surface for $5 \mathrm{~s}$. Then, the adhesive system was photoactivated through a Bluephase $\mathrm{N}$ lightpolymerizing unit (Ivoclar, Barueri, SP, Brazil) at a high power intensity of $1430 \mathrm{~mW} / \mathrm{cm}^{2}$, following the manufacturer's recommendation, for $10 \mathrm{~s}$.

The volatilization of the adhesive system was carried out by using a portable sample heating device (ER 27110; Erios) developed by the Dentistry Laboratory of the Faculty of Dentistry of Piracicaba- UNICAMP (patented), at a standardized 
distance of $7 \mathrm{~cm}$ between the tip of the applicator cannula and the tooth surface. The air jet was used at a constant temperature of $40 \pm 1^{\circ} \mathrm{C}$ or $23 \pm 1^{\circ} \mathrm{C}$.

\subsection{Composite resin restoration}

The composite resin used was Filtek Bulk Fill resin Posterior Restorative (3M, St. Paul, MN, USA) and was restored using the single-increment restorative technique for up to $4 \mathrm{~mm}$. Photoactivation was conducted using a Bluephase $\mathrm{N}$ device (Ivoclar, Barueri, SP, Brazil) with a high power intensity of $1430 \mathrm{~mW} / \mathrm{cm}^{2}$, following the manufacturer's recommendation, for $20 \mathrm{~s}$.

\subsection{Temperature rating}

Through the opening in the sectioned root, a thermal paste was inserted (Implastec Electroquímica, Votorantim - SP, BR) and a thermometer sensor with a type K thermocouple (TES, Neihu Dist., Taipei, Taiwan) was introduced in the pulp chamber, maintaining contact with the center of the top surface of pulp chamber (Schneider, et al, 2005, Andreatta, et al., 2016).

. Root surfaces and the lower portion of the crown were submerged in a thermal vat, where the water was maintained at a constant temperature of $37 \pm 1{ }^{\circ} \mathrm{C}$ (Andreatta, et al., 2016). The pulp chamber temperature was measured at different times (stages of the restorative protocol): $10 \mathrm{~min}$ after the tooth is subjected to stable cavity preparation in water at $37 \pm 1{ }^{\circ} \mathrm{C}(\mathrm{I})$, immediately after volatilization of the adhesive system (V), immediately after photoactivation of the adhesive system (A), and immediately after photoactivation of the composite resin (C). The temperature was measured for $5 \mathrm{~min}$ at each of the abovementioned times.

\section{Statistical Analysis}

To verify the assumptions of the normality of the errors and homoscedasticity, the Shapiro Wilk and Levene tests were conducted. Subsequently, two-way and three-way analysis of variance was carried out, followed by Tukey's post-hoc analysis $(\alpha=0.05)$. The analysis was performed using software R (University of Auckland, Auckland, North Island, New Zealand).

\section{Results}

The solvent volatilization protocol with the heated air jet influenced the results of volatilization of the pulp chamber for middle cavity $(p=0.0017)$, very deep cavity $(p=0.0173)$, and control group $(p=0.0014)$. By determining the cavity depth for each group in the volatilization protocol, compared to the conventional protocol, a higher temperature measure was observed for very deep cavity $\left(37.4^{\circ} \mathrm{C}\right)$, deep cavity $\left(37.2^{\circ} \mathrm{C}\right)$, and shallow cavity $\left(36.9^{\circ} \mathrm{C}\right)$ groups. Comparatively, for the heated air jet, the highest temperature variations were observed for very deep cavity $\left(37.7^{\circ} \mathrm{C}\right)$ and deep cavity $\left(37.4^{\circ} \mathrm{C}\right)$ groups.

As for the initial averages $\left(36.8^{\circ} \mathrm{C}\right)$ and those obtained after volatilization $\left(36.9^{\circ} \mathrm{C}\right)$ were lower and statistically similar; further, the photoactivation temperatures required for the adhesive system $\left(37.2^{\circ} \mathrm{C}\right)$ and restoration $\left(37.8^{\circ} \mathrm{C}\right)$ were observed to be greater (Figures 2 and 3). 
Figure 2 - Graphical representation of average temperatures at different cavity depths and stages of restoration in the conventional protocol for solvent volatilization.

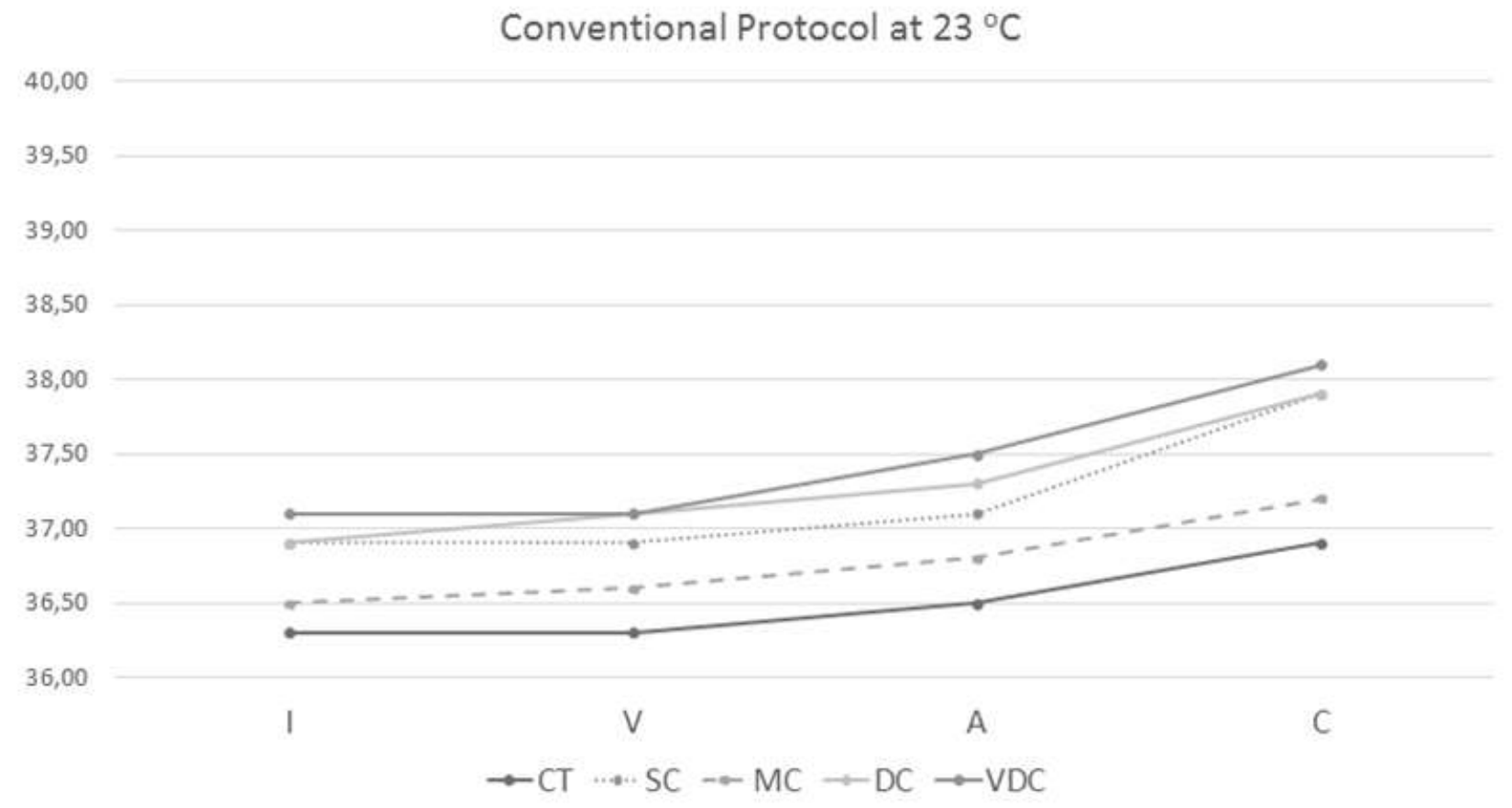

Source: Authors.

Figure 3 - Graphical representation of the average temperatures in the different cavities and stages of restorations in the heated air protocol for solvent volatilization.

\section{Heating Protocol at $40^{\circ} \mathrm{C}$}

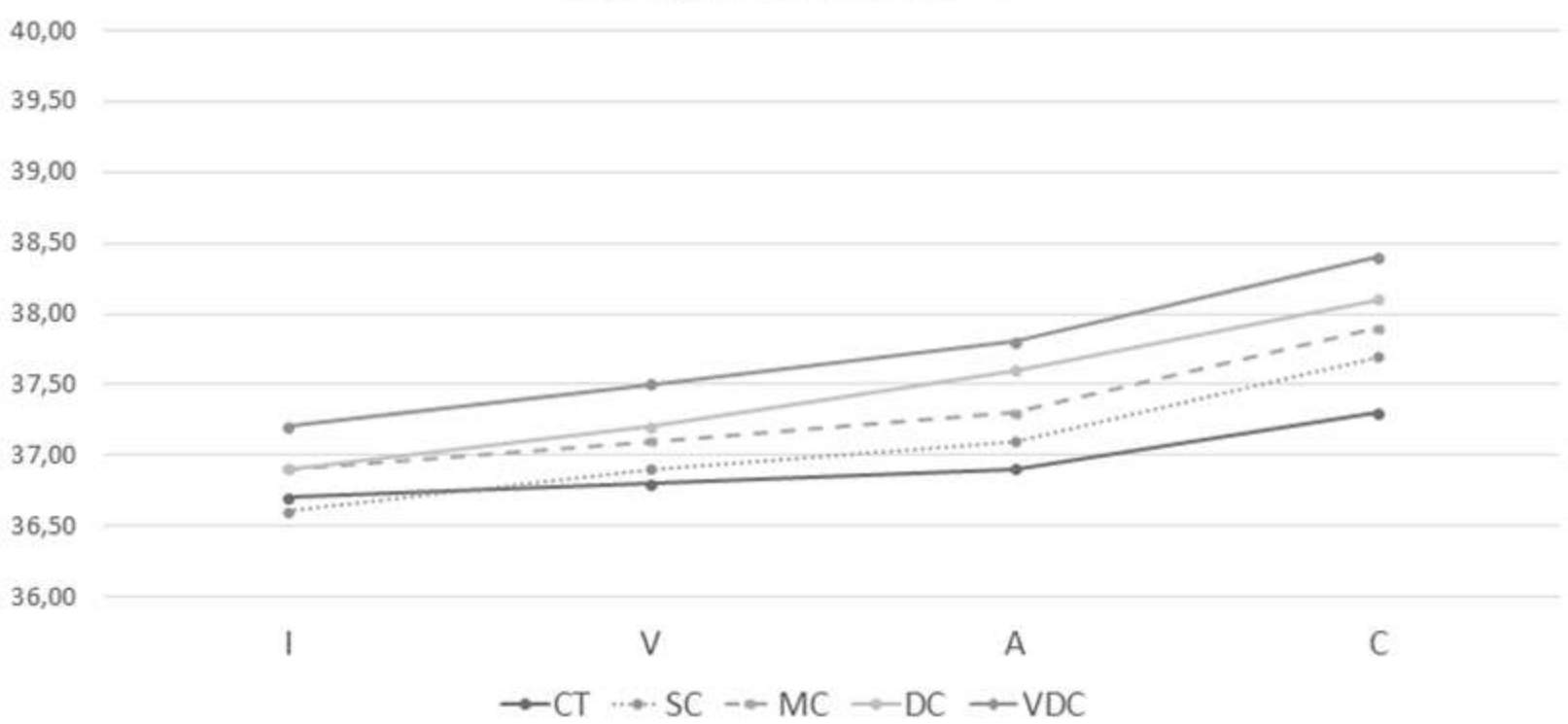

Source: Authors.

The average values of the temperature variation between each restorative stage, at 23 and $40{ }^{\circ} \mathrm{C}$, are described in Table 1 for the different cavity depths that were evaluated. When comparing the groups of teeth restored for the different solvent 
volatilization protocols evaluated $\left(\mathrm{CP}-23^{\circ} \mathrm{C}\right.$ or $\left.\mathrm{HP}-40^{\circ} \mathrm{C}\right)$, a statistically significant difference was not observed between the stages of the photoactivation of the adhesive system and the photoactivation of the composite resin regardless of the cavity depth studied ( $p>0.05)$.

Table 1 - Average variation of pulp temperature in ${ }^{\circ} \mathrm{C}$ from the average pulp temperature ( 36.2 to $37{ }^{\circ} \mathrm{C}$ ) in the different cavity depths and stages of restoration according to the air jet temperature for volatilization.

\begin{tabular}{|c|c|c|c|c|c|c|}
\hline & \multicolumn{2}{|c|}{ Volatilization } & \multicolumn{2}{|c|}{ Adhesive } & \multicolumn{2}{|c|}{ Composite } \\
\hline Deep & $\mathrm{CP}\left(23^{\circ} \mathrm{C}\right)$ & $\mathrm{HP}\left(40^{\circ} \mathrm{C}\right)$ & $\mathrm{CP}\left(23^{\circ} \mathrm{C}\right)$ & $\mathrm{HP}\left(40^{\circ} \mathrm{C}\right)$ & $\mathrm{CP}\left(23^{\circ} \mathrm{C}\right)$ & $\mathrm{HP}\left(40^{\circ} \mathrm{C}\right)$ \\
\hline VDC & 0,04 $(0,09) \mathrm{Bab}$ & $0,31(0,16) \mathrm{Aa}$ & $0,40(0,19)$ Aab & $0,48(0,29)$ Aab & $0,94(0,31) \mathrm{Aa}$ & $1,06(0,27) \mathrm{Aa}$ \\
\hline DC & $0,07(0,10) \mathrm{Bab}$ & $0,27(0,09) \mathrm{Aa}$ & $0,58(0,28) \mathrm{Aa}$ & $0,59(0,22) \mathrm{Aa}$ & $1,00(0,53) \mathrm{Aa}$ & $1,05(0,31) \mathrm{Aa}$ \\
\hline MC & $0,15(0,08) \mathrm{Aa}$ & $0,2(0,11)$ Aab & $0,54(0,53) \mathrm{Aa}$ & $0,44(0,21) \mathrm{Aa}$ & $0,62(0,52) \mathrm{Aab}$ & $0,94(0,35) \mathrm{Aab}$ \\
\hline SC & $0,00(0,11) \mathrm{Bb}$ & $0,26(0,11) \mathrm{Aa}$ & $0,21(0,24) A b c$ & $0,31(0,12) A b c$ & $1,00(0,27) \mathrm{Aa}$ & $0,88(0,30) \mathrm{Aa}$ \\
\hline CT & $-0,01(0,06) \mathrm{Bb}$ & $0,11(0,06) A b$ & $0,17(0,15) A c$ & $0,19(0,10) A c$ & $0,50(0,41) A b$ & $0,59(0,27) A b$ \\
\hline
\end{tabular}

Source: Authors.

However, during the volatilization stage of the adhesive system, a small increase in pulp temperature variation was observed when dentin was volatilized at $40^{\circ} \mathrm{C}(\mathrm{p}=0.0175)$ in cavities of varying depths, namely: shallow $\left(0.26^{\circ} \mathrm{C}\right)$, deep $(0.27$ $\left.{ }^{\circ} \mathrm{C}\right)$, and very deep $\left(0.31^{\circ} \mathrm{C}\right)$.

The average temperature increase for the photoactivation stage of the adhesive system ranged from 0.17 to $0.59{ }^{\circ} \mathrm{C}$, with a greater variation on an average in the cavities that were shallow cavity $\left(\mathrm{CP}-0.54{ }^{\circ} \mathrm{C}\right.$; $\left.\mathrm{HP}-0.44{ }^{\circ} \mathrm{C}\right)$, deep cavity $(\mathrm{CP}-0.58$ ${ }^{\circ} \mathrm{C}$; HP- $\left.0.59^{\circ} \mathrm{C}\right)$, and very deep cavity $\left(\mathrm{CP}-0.40{ }^{\circ} \mathrm{C} ; \mathrm{HP}-0.48^{\circ} \mathrm{C}\right)(\mathrm{p}<0.05)$.

During the photoactivation stage of the composite resin, the pulp temperature of all the teeth, regardless of the cavity depth, was observed to exhibit the highest increase in temperature with average increases ranging from 0.50 to $1.06{ }^{\circ} \mathrm{C}$; this led to a variety of peaks in the shallow cavity $\left(\mathrm{CP}-1.0{ }^{\circ} \mathrm{C}\right.$; HP- $0.88^{\circ} \mathrm{C}$ ), medium cavity $\left(\mathrm{CP}-0.62{ }^{\circ} \mathrm{C}\right.$; $\left.\mathrm{HP}-0.94{ }^{\circ} \mathrm{C}\right)$, deep cavity $\left(\mathrm{CP}-1.00{ }^{\circ} \mathrm{C}\right.$; HP- $\left.1.05^{\circ} \mathrm{C}\right)$, and very deep cavity $\left(\mathrm{CP}-0.94{ }^{\circ} \mathrm{C} ; \mathrm{HP}-1.06{ }^{\circ} \mathrm{C}\right)(\mathrm{p}<0.05)$.

\section{Discussion}

The scientific interest in protocols that improve the quality of the adhesive layer and the hybrid layer has resulted in the formation of composite resin restorations with enhanced resistances; this has been achieved via inspiring research based on the volatilization of solvents with rising temperatures (Alexandre, et al., 2008; Klein-Júnior, et al., 2008; Reis, et al., 2009; Reis, et al., 2010; Ogura, et al., 2012; Ferreira-Barbosa, et al., 2020). However, because heat can be a critical factor that can lead to pulp heating, there is a concern regarding the investigation of the effects of the rise in temperature of the air jet on safety with regard to changing restorative clinical protocols without causing structural changes in the dental pulp. The null hypothesis tested that the heated air jet would negatively influence the temperature of the pulp chamber regardless of cavity depth was rejected.

It is well-known that if the critical pulp heating threshold is reached or exceeded, the resulting changes can lead to a variety of problems including irreversible pulpitis to pulp necrosis (Zach \& Cohen, 1965; Baldi, et al., 2019; Karacan \& Ozyurt, 2019; Nilsen, et al., 2020). In this context, it has been established that the smaller the dentin thickness remaining in a cavity preparation, the greater the proximity to the dental pulp; consequently, this increases the chances of aggressive agents in the 
dentin to reach the odontoblast extensions (Kwon, et al., 2013; Vinall, et al., 2017; Yasa, et al., 2017; Akarsu \& Aktuğ Karademir, 2019).

In the comparison between the cavity depths evaluated, it was found that the remaining dentin thickness was extremely important and it influenced the results obtained in this study. Thus, with the increase in the temperature of the pulp chamber, there was a significant effect on the restorations performed in very deep cavities (less than $0.5 \mathrm{~mm}$ dentin thickness). In this context (Kwon, et al., 2013; Niu, et al., 2016), researchers have associated this influence of temperature on procedures that generate heat in the proximity of the pulp tissue; further, they have also attributed this effect on the larger diameter of the dentinal tubules in this region that results in a greater thermal conductivity, rendering the pulp to respond faster. The results obtained in this study confirm that the greater the depth, the greater the variation of the pulp temperature.

In view of the results presented in this study, there was an increase in the overall pulp temperature; the greatest variation occurred in the resin photoactivation stage, with a peak reaching a variation of $1.06^{\circ} \mathrm{C}$ under the temperature range varying from $37.3^{\circ} \mathrm{C}$ to $38.4^{\circ} \mathrm{C}$. This was observed primarily in cavities that were closer to the pulp, reinforcing the fact that the dentin thickness is inversely proportional to the the pulp chamber temperature (Niu, et al., 2016; Silva, et al., 2018). From this point of view, studies have demonstrated that two factors are responsible for the increase in the temperature of the pulp chamber, namely: the exothermic reaction of the carbon-carbon conversion of double bonds and the absorption of light energy during photoactivation that also causes an exothermic reaction and can elucidate the results obtained (Hubbezoglu, et al., 2008; Chang, et al., 2013; Kim, et al., 2015).

However, studies show that the variation capable of altering the pulp tissue is $5.5^{\circ} \mathrm{C}$ above the average temperature of the oral cavity that varies from 36.2 to $37^{\circ} \mathrm{C}{ }^{\circ} \mathrm{C}$ (Zach \& Cohen, 1965; Baldi, et al., 2019; Karacan \& Ozyurt, 2019; Nilsen, et al., 2020), with $42-42.5^{\circ} \mathrm{C}$ being the average critical pulp temperature to initiate irreversible damage (Pohto \& Scheinin, 1958). Thus, in this study, although it was the restorative stage that presented the greatest temperature variation, the photoactivation of the Filtek Bulk Fill Posterior Restorative resin at different cavity depths that was evaluated for the different solvent volatilization protocols did not attain the critical pulp temperature average.

With the recent advances in composites and the development of restorative materials called bulk fill, which can be inserted into the cavity in increments of up to $4 \mathrm{~mm}$ thickness (Fronza, et al., 2015; Kapoor, et al., 2016; Eweis, et al., 2018; Boaro, et al., 2019; Arbildo-Vega, et al., 2020), additional photoactivation is unnecessary as that required for conventional resins (AlShaafi, 2017; Zarpellon, et al., 2018); this reduces stress, polymerization contraction, and working time (Fronza, et al., 2015; Rosatto, et al., 2015; Reis, et al., 2017).

In addition to the advantages mentioned, this composite was photoactivated for only $20 \mathrm{~s}$, following the manufacturer's recommendation; this is because the photoactivator had an intensity exceeding $1000 \mathrm{~mW} / \mathrm{cm}^{2}$ (Campodonico, et al., 2011; Yarmohammad, et al., 2019), which may also have contributed to the maintenance of the pulp temperature at the safe threshold of variation (Zach \& Cohen, 1965; Baldi, et al., 2019; Karacan \& Ozyurt, 2019; Nilsen, et al., 2020).

In the comparison between the groups of teeth restored for the different volatilization protocols of the evaluated solvents, no difference was observed between the restorative stages of the photoactivation of the adhesive system and the composite resin; this was observed regardless of the cavity depth. This suggests that volatilization with a heated air jet did not result in an increase in the temperature of the pulp chamber during the application of the light source by somatization.

In this study, an air jet was used to volatilize the solvents present in the Universal Single Bond adhesive system under two distinct temperatures, 23 or $40{ }^{\circ} \mathrm{C}$, whose maximum temperature did not even reach $38{ }^{\circ} \mathrm{C}$; this was observed regardless of the group in question, remaining in a safe variation zone (Pohto \& Sheinin, 1958; Zach \& Cohen, 1965; Baldi, et al., 2019; Karacan \& Ozyurt, 2019). 
Under the conventional protocol, the highest temperature peak was reached at the restorative procedure performed in a very deep cavity at $37.4{ }^{\circ} \mathrm{C}$. The protocol that required a temperature of $40{ }^{\circ} \mathrm{C}$ also showed its highest peak in the very deep cavity at $37.7^{\circ} \mathrm{C}$. These data corroborate the previous findings by Silva et al., 2018, wherein it was found that the pulp chamber temperature is influenced by the thickness of the remaining dentin (Kwon, et al., 2013; Vinall, et al., 2017; Yasa, et al., 2017; Akarsu \& Aktuğ Karademir, 2019,) as well as by the evaporation temperature of the solvent in the adhesive system (Silva, et al., 2018; Carvalho, et al., 2019).

The results of this study contradict the previous findings by Silva et al., 2018 wherein the average temperature variation was from 4.1. to $16.6^{\circ} \mathrm{C}$, regardless of the cavity depth; however, this was obserevd with a jet of air heated to $60 \pm 2^{\circ} \mathrm{C}$ and with volatilization time ranging from 10 to $40 \mathrm{~s}$ (Silva, et al., 2018). It is suggested that the difference in the volatilization times, equipment used, and the lower pressure as well as outflow of the air jet of the equipment used in this study were responsible for the small temperature variation observed even in very deep cavities.

Fortunately, several studies have been insistent in seeking to improve the adhesion capacity and the mechanical properties of adhesive restorations (Ogura, et al., 2012; Fidalgo, et al., 2019; Zhou, et al., 2019). As previously mentioned, volatilization with heated air has led to an increase in mechanical and physical properties (Alexandre, et al., 2008; Klein-Júnior, et al., 2008; Reis, et al., 2009; Reis, et al., 2010; Ogura, et al., 2012; Ferreira-Barbosa, et al., 2020). However, there are still a few numbers of studies that have successfully determined the possibility of pulp aggression. Thus, in this investigation, the evaporation of solvents in a universal adhesive system using a heated air jet showed promising results, with regard to maintaining the pulp tissue temperature in the safe range (Pohto \& Sheinin, 1958; Zach \& Cohen, 1965; Baldi, et al., 2019; Karacan \& Ozyurt, 2019) even in the very deep cavity.

It is known that the likelihood of injury to the pulp during restorative procedures depends on not only the peak of the temperature attained, but also on the time for which this temperature remains above a safe threshold (Baldissara, et al., 1997; Silva, et al., 2018; Runnacles, et al., 2019). In this context, the protocol stipulated for the time of volatilization and photoactivation of the restorative steps evaluated in this research were based on the indications of the manufacturers of each material. Remarkably, the times studied at the evaluated temperatures remained in accordance with their peaks and averages of the temperature variation, within the safe threshold of variation.

It is important to clarify no covering materials were used that in this study, such as calcium hydroxide cement and glass ionomer cement, which are indicative for cavities that are in a greater proximity to the pulp environment and could prevent injuries to this tissue during clinical restorative practice (Corralo \& Maltz, 2013; Arandi, 2017).

Such materials were not used in this study purely for the purpose of standardizing the influence of the temperature on the different volatilization protocols evaluated. Thus, clinically, the protection of the pulp with protective materials of the pulp dentin complex, such as cements, is observed when dealing with deep and very deep cavities; this is in order to avoid its heating at various restorative stages, depending on the type of technique and the composite resin used.

In this study, despite the conditions being favorable and mimicking clinical conditions, one must take into account the limitations that a laboratory study presents, but the results found are important for the scientific basis and encourage further studies.

The use of the heated air jet for the volatilization of the adhesive system resulted in minimal changes in pulp heating; this was in contrast to the photoactivation of the adhesive system and the composite resin, wherein the heating was increased with the cavity depth even though critical thresholds were not achieved. 


\section{Conclusions}

- The use of the heated air jet for volatilization of the universal adhesive system solvent as one of the restorative steps in the Bulk Fill resin restoration resulted in a small temperature increase in the pulp chamber; however, the critical threshold of temperature variation was not achieved. The procedure can be considered safe with the evaluated equipment.

- Pulp temperature variations observed did not reach critical levels despite being influenced by the photoactivation of the adhesive system and the composite resin.

- The temperature in the pulp chamber was influenced by the dentin thickness. This implies that the dental surgeon had properly performed the restorative protocol.

\section{Acknowledgements}

This study was supported by the University of Western São Paulo (PPG/PEIC/UNOESTE - 4353).

\section{Conflict of Interest Statement}

The authors would like to disclose that Dr. Larissa Sgarbosa de Araújo Matuda is the inventor of a pending BR Patent (\# 11049898) "Heated air jet device and its use" held by the Board of Trustees of the University of Campinas - UNICAMP.

\section{References}

Arbildo-Vega, H. I., Lapinska, B., Panda, S., Lamas-Lara, C., Khan, A. S., \& Lukomska-Szymanska, M. (2020). Clinical Effectiveness of Bulk-Fill and Conventional Resin Composite Restorations: Systematic Review and Meta-Analysis. Polymers, 12(8), 1786. https://doi.org/10.3390/polym12081786

Akarsu, S., \& Aktuğ Karademir, S. (2019). Influence of Bulk-Fill Composites, Polimerization Modes, and Remaining Dentin Thickness on Intrapulpal Temperature Rise. Biomed Res Int., 2019:4250284.

Alexandre, R. S., Sundfeld, R. H., Giannini, M., \& Lovadino, J. R. (2008). The influence of temperature of three adhesive systems on bonding to ground enamel. Oper Dent, 33, 272-81.

AlShaafi, M. M. (2018). Factors affecting polymerization of resin-based composites: A literature review. Saudi Dent J, 29(2), 48-58.

Amaral, C. M., Diniz, A. M., Arantes, E. B., Dos Santos, G. B., Noronha-Filho, J. D., \& da Silva, E. M. (2016). Resin-dentin Bond Stability of Experimental 4META-based Etch-and-rinse Adhesives Solvated by Ethanol or Acetone. J Adhes Dent, 18(6), 513-520.

Andreatta, L. M. L., Furuse, A. Y., Prakki, A., Bombonatti, J. F. A., \& Mondelli, R. F. L. (2016). Pulp Chamber Heating: An In Vitro Study Evaluating Different Light Sources and Resin Composite Layers. Brazilian Dental Journal, 27(6), 675-680.

Arandi, N.Z. (2017). Calcium hydroxide liners: a literature review. Clin Cosmet Investig Dent, 9, 67-72.

Baldi, D., Colombo, J., Robiony, M., Menini, M., Bisagni, E., \& Pera, P. (2019). Temperature variations in pulp chamber: an in vitro comparison between ultrasonic and rotating instruments in tooth preparation. Minerva Stomatol, 10.23736/S0026-4970.19.04279-1.

Baldissara, P., Catapano, S., \& Scotti, R. (1997). Clinical and histological evaluation of termal injury thresholds in human teeth: a preliminarystudy. J Oral Rehabil, 24(11), 791-801.

Boaro, L. C. C., Lopes, D. P., de Souza, A. S. C., Nakano, E. L., Perez, M. D. A., Pfeifer, C. S., \& Gonçalves, F. (2019). Clinical Performance and ChemicalPhysical Properties of Bulk Fill Composites Resin -A Systematic Review and Meta-Analysis Dent Mater, 35(10), e249-e264.

Borgo, G. O., Vieira-Junior, W. F., Theobaldo, J. D., Aguiar, F. H. B., \& Lima, D. A. N. L. (2019). Effect of Dentin Pretreatment with Arginine on Microshear Bond Strength of Etch-and-Rinse or Self-Etch Adhesive Systems. Eur J Dent, 13(2), 199-205.

Caiado, A. C., de Goes, M. F., de Souza-Filho, F. J., \& Rueggeberg, F. A. (2010). The effect of acid etchant type and dentin location on tubular density and dimension. J Prosthet Dent, 103(6), 352-61.

Campodonico, C. E., Tantbirojn, D., Olin, P. S., \& Versluis. A, (2011). Cuspal deflection and depth of cure in resin-based composite restorations filled by using bulk, incremental and transtooth-illumination techniques. J Am Dent Assoc, 142(10), 1176-1182.

Carvalho, C. N., Lanza, M. D. S., Dourado, L. G., Carvalho, E. M., \& Bauer, J. (2019). Impact of Solvent Evaporation and Curing Protocol on Degree of Conversion of Etch-and-Rinse and Multimode Adhesives Systems. Int J Dent, 2019:5496784.

Chang, H. S., Cho, K. J., Park, S. J., Lee, B. N., Hwang, Y. C., Oh, W. M., \& Hwang, I. N. (2013). Thermal analysis of bulk filled composite resin polymerization using various light curing modes according to the curing depth and approximation to the cavity wall. J Appl Oral Sci, 21, $293-299$. 
Chiba, A., Zhou, J., Nakajima, M., Tan, J., Tagami, J., Scheffel, D. L., Hebling, J., Agee, K. A., Breschi, L., Grégoire, G., Jang, S. S., Tay, F. R., \& Pashley, D. H. (2016). The effects of ethanol on the size-exclusion characteristics of type I dentin collagen to adhesive resin monomers. Acta Biomater, 33, 235-41.

Corralo, D. J., \& Maltz, M. (2013). Clinical and ultrastructural effects of different liners/restorative materials on deep carious dentin: a randomized clinical trial. Caries Res, 47(3), 243-250.

De Munck, J., Van Landuyt, K., Peumans, M., Poitevin, A., Lambrechts, P., Braem, M., \& Van Meerbeek, B. (2005). A critical review of the durability of adhesion to tooth tissue: methods and results. J Dent Res, 84(2), 118-32.

Dreweck, F., Burey, A., de Oliveira Dreweck, M., Loguercio, A. D., \& Reis, A. (2021). Adhesive strategies in cervical lesions: systematic review and a network meta-analysis of randomized controlled trials. Clinical oral investigations, 25(5), 2495-2510. https://doi.org/10.1007/s00784-021-03844-5.

Eweis, A. H., Yap, A. U., \& Yahya, N. A. (2018). Impact of dietary solvents on flexural properties of bulk-fill composites. Saudi Dent J, 30 (3), $232-239$.

Ferreira-Barbosa, I., Araújo-Pierote, J. J., Rodrigues de Menezes, L., Trazzi-Prieto, L., Frazão-Câmara, J. V., Sgarbosa de Araújo-Matuda, L., Marchi, G. M., Maffei Sartini-Paulillo, L. A., \& Pimenta de Araujo, C. T. (2020). Effect of alternative solvent evaporation techniques on mechanical properties of primeradhesive mixtures. Efeito de técnicas alternativas utilizando evaporação de solvente nas propriedades mecânicas da mistura primer-adesivo. Acta odontologica latinoamericana : AOL, 33(2), 135-142.

Fidalgo, T. K. D. S., Americano, G., Medina, D., Athayde, G., Letieri, A. D. S., \& Maia, L. C. (2019) Adhesiveness of bulk-fill composite resin in permanent molars submitted to Streptococcus mutans biofilm. Braz Oral Res, 33, e111.

Fronza, B. M., Rueggeberg, F. A., Braga, R. R., Mogilevych, B., Soares, L. E., Martin, A. A., Ambrosano, G., \& Giannini, M. (2015). Monomer conversion, microhardness, internal marginal adaptation, and shrinkage stress of bulk-fill resin composites. Dent Mater, 31(12), $1542-51$.

Giannini, M., Arrais, C. A., Vermelho, P. M., Reis, R. S., dos Santos, L. P., \& Leite, E. R. (2008). Effects of the Solvent Evaporation Technique on the Degree of Conversion of One-Bottle Adhesive Systems. Oper Dent, 33(2), 149-54.

Hannig, M., \& Bott, B. (1999). In-vitro pulp chamber temperature rise during composite resin polymerization with various light-curing sources. Dent Mater, $15(4), 275-81$.

Hubbezoglu, I., Dogan, A., Dogan, O. M., Bolayir, G., \& Bek, B. (2008). Effects of light curing modes and resin composites on temperature rise under human dentin: an in vitro study. Dent Mater J, 27, 581-589.

Huang, F. M., Li, Y. C., Lee, S. S., \& Chang, Y. C. (2010). Cytotoxicity of dentine bonding agents on human pulp cells is related to intracellular glutathione levels. Int Endod J, 43(12), 1091-7.

Karacan, A. O., \& Ozyurt, P. (2019). Effect of preheated bulk-fill composite temperature on intrapulpal temperature increase in vitro. J Esthet Restor Dent, $31(6), 583-588$

Kapoor, N., Bahuguna, N., \& Anand, S. (2016). Influence of composite insertion technique on gap formation. J Conserv Dent, 19, 77-81.

Kim, R. J. Y., Son, S. A., Hwang, J. Y., Lee, I. B., \& Seo, D. G. (2015). Comparison of photopolymerization temperature increases in internal and external positions of composite and tooth cavities in real time incremental fillings of microhybrid composite vs. bulk filling of bulk fill composite. J Dent, 43 , 10931098.

Klein-Júnior, C. A., Zander-Grande, C., Amaral, R., Stanislawczuk, R., Garcia, E. J., Baumhardt-Neto, R., Meier, M. M., Loguercio, A. D., \& Reis, A. (2008). Evaporating solventes with a warm air stream: effects on adhesive layer properties and resin-dentin bond strengths. J Dent, 36, 618-25.

Kwon, S. J., Park, Y. J., Jun, S. H., Ahn, J. S., Lee, I. B., Cho, B. H., Son, H. H., \& Seo, D. G. (2013). Thermal irritation of teeth during dental treatment procedures. Restor Dent Endod, 38(3), 105-112.

Matuda, L. S., Marchi, G. M., Aguiar, T. R., Leme, A. A., Ambrosano, G. M., \& Bedran-Russo, A. K. (2016). Dental adhesives and strategies for displacement of water/solvents from collagen fibrils. Dent Mater, 32(6), 723-31.

Nasseri, E. B., \& Eskandarizadeh, A. (2020). Comparative study of different cytotoxicity of bonding systems with different dentin thickness on L929 cell line: An experimental study. Dental research journal, 17(6), 424-432.

Niu, L., Dong, S. J., Kong, T. T., Wang, R., Zou, R., \& Liu, Q. D. (2016). Heat Transfer Behavior across the Dentino-Enamel Junction in the Human Tooth. PLoS One, 11(9), e0158233.

Nilsen, B. W., Mouhat, M., Haukland, T., Örtengren, U. T., \& Mercer, J. B. (2020). Heat Development in the Pulp Chamber During Curing Process of ResinBased Composite Using Multi-Wave LED Light Curing Unit. Clinical, cosmetic and investigational dentistry, 12, 271-280. https://doi.org/10.2147/CCIDE.S257450

Ogura, Y., Shimizu, Y., Hiratsuchi, K., Tsujimoto, A., Takamizawa, T., Ando, S., \& Miyazaki, M. (2012). Effect of warm air-drying on dentin bond strength of single-step self-etch adhesives. Dent Mat J, 31(4), 507-13.

Osorio, R., Osorio, E., Tay, F. S. A. F. R., Pinto, A., \& Toledano, M. (2010). Influence of application parameters on bond strength of an "all in one" water-based self-etching primer/adhesive after 6 and 12 months of water aging. Odontology, 98(2), 117-25.

Pohto, M., \& Scheinin, A. (1958). Microscopic observations on living dental pulp. Acta Odontol Scand, 16, 303-327.

Reis, A., Klein-Júnior, C. A., Accorinte, M. L. R., Grande, R. H. M., dos Santos, C. B., \& Loguercio, A. D. (2009). Effects of adhesive temperature on the early and 6-month dentin bonding. $J$ Dent, 37, 791-8. 
Reis, A., Klein-Junior, C. A., Coelho de Souza, F. H., Stanislawczuk, R., \& Loguercio, A.D. (2010). The use of warm air stream for solvente evaporation: effects on the durability of resin-dentin bonds. Oper Dent, 35(1), 9-36.

Reis, A. F., Vestphal, M., Amaral, R. C. D., Rodrigues, J. A., Roulet, J. F., \& Roscoe, M. G. (2017). Efficiency of polymerization of bulk-fill composite resins: a systematic review. Braz Oral Res, 28, 31(suppl 1):e59.

Rosatto, C. M., Bicalho, A. A., Veríssimo, C., Bragança, G. F., Rodrigues, M. P., Tantbirojn, D., Versluis, A., \& Soares, C. J. (2015). Mechanical properties, shrinkage stress, cuspal strain and fracture resistance of molars restored with bulk-fill composites and incremental filling technique. J Dent, 43(12), 1519-1528.

Runnacles, P., Arrais, C. A. G., Maucoski, C., Coelho, U., De Goes, M. F., \& Rueggeberg, F. A. (2019). Comparison of in vivo and in vitro models to evaluate

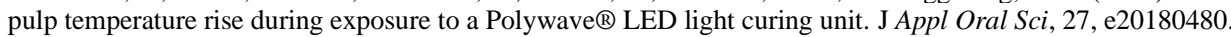

Schneider, L. F. J., Cavalcante, L. M. A., Tango, R. N., Consani, S., Sinhoreti, M. A. C., \& Correr Sobrinho, L. (2005). Pulp chamber temperature changes during resin composite photo-activation. Brazilian Journal of Oral Science, 4(12), 685-8.

Silva, E. M. D., Penelas, A. G., Simmer, F. S., Paiva, R. V., Moreira E Silva, V. L., \& Poskus, L. T. (2018). Can the Use of a Warm-Air Stream for Solvent Evaporation Lead to a Dangerous Temperature Increase During Dentin Hybridization? J Adhes Dent, 20(4), 335-340.

Van Landuyt, K. L., Snauwaert, J., De Munck, J., Peumans, M., Yoshida, Y., Poitevin, A., Coutinho, E., Suzuki, K., Lambrechts, P., \& Van Meerbeek, B. (2007). Systematic review of the chemical composition of contemporary dental adhesives. Biomaterials, 28(26), 3757-85.

Vinall, C. V., Garcia-Silva, T. C., Lou, J. S. B., Wells, M. H., Tantbirojn, D., \& Versluis, A. (2017). Intrapulpal Temperature Rise During Light Activation of Restorative Composites in a Primary Molar. Pediatr Dent, 39(3), 125-130.

Yarmohammadi, E., Kasraei, S., \& Sadeghi, Y. (2019). Comparative Assessment of Cuspal Deflection in Premolars Restored with Bulk-Fill and Conventional Composite Resins. Frontiers in dentistry, 16(6), 407-414. https://doi.org/10.18502/fid.v16i6.3439

Yasa, E., Atalayin, C., Karacolak, G., Sari, T., \& Turkun, L. S. (2017). Intrapulpal temperature changes during curing of different bulk-fill restorative materials. Dent Mater, 26;36(5), 566-572.

Zach, L., \& Cohen, G. (1965). Pulp response to externally aplied heat. Oral Surg Oral Med Oral Pathol, 19, 515-30.

Zarpellon, D. C., Runnacles, P., Maucoski, C., Gross, D. J., Coelho, U., Rueggeberg, F. A., \& Arrais, C. A. G. (2018). Influence of Class V Preparation on in Vivo Temperature Rise in Anesthetized Human Pulp During Exposure to a Polywave ${ }^{\circledR}$ LED Light Curing Unit, 34(6), 901-909.

Zarpellon, D. C., Runnacles, P., Maucoski, C., Coelho, L., Rueggeberg, F. A., \& Arrais, C. (2019). Controlling In Vivo, Human Pulp Temperature Rise Caused by LED Curing Light Exposure. Oper Dent, 44(3), 235-241.

Zhou, W., Liu, S., Zhou, X., Hannig, M., Rupf, S., Feng, J., Peng, X., \& Cheng, L. (2019). Modifying Adhesive Materials to Improve the Longevity of Resinous Restorations. Int J Mol Sci, 20(3), 723. 